\title{
Foraminifera and Ostracods from the Dinantian Woodbine Shale and Urswick Limestone, South Cumbria, U.K.
}

\author{
J. ATHERSUCH \& A.R.E. STRANK \\ BP Research Centre, Chertsey Road, Sunbury-on-Thames, U.K.
}

\begin{abstract}
Macrofaunal and foraminiferal analyses have shown the Woodbine Shale in South Cumbria to be of latest early Asbian age. Ostracods and solid foraminifera from the Woodbịne Shale are described and illustrated for the first time. Several ostracods including Rectobairdia cf. dorssenata, Healdia 'penchfordensis', Bairdia cf. leguminoides, Pustulobairdia cf. confragosa and Microcheilinella subcorbulinoides, previously only known from late Asbian or younger strata, have now been shown to range into the early Asbian. The numerous bairdiids, heavily ornamented ostracods, trilobites, brachiopods and abundant foraminifera suggest a deep, subtidal, marine environment of deposition for the Woodbine Shale. Foraminifera from the underlying Lower Urswick Limestone suggest an early Asbian age for this formation whilst the overiying Upper Urswick Limestone is shown to be of late Asbian age. The foraminiferal assemblages from these beds can be correlated directly with those in the early Asbian Upper Potts Beck Limestone and the late Asbian Knipe Scar Limestone in the Asbian stratotype section at Little Asby Scar, Cumbria.
\end{abstract}

\section{INTRODUCTION}

During the Lower Carboniferous in South Cumbria a thick shelf limestone succession (c. $600 \mathrm{~m}$ ) of Tournaisian to Brigantian rocks was deposited on top of a dissected Lower Palaeozoic land surface. Various attempts have been made to correlate and date these rocks, notably by Aveline (1873), Garwood (1913), Dunham \& Rose (1941), Ramsbottom (1973) and Mitchell (in Rose \& Dunham, 1977) but some doubt still exists as to the age of certain units. The summarised stratigraphy of the area in Figure 1 shows the presence of a shale horizon within the Urswick Limestone. This thick shale is unique to South Cumbria where it is exposed over much of the area from Silverdale to Furness. Particularly good exposures of the Urswick Limestone and the Woodbine shale are seen at Trowbarrow Quarry near Silverdale (SD 4800 7575 ) and Crown Quarries near Dalton-in-Furness (SD 2490 7280) (Figure 2).

Detailed microfaunal examination of the underlying and overlying Urswick Limestone has yielded abundant foraminiferal assemblages which have been identified in random thin section (Strank, 1981). In Trowbarrow Quarry the richly calcareous Woodbine Shale unit proved to be particularly prolific in terms of both foraminifera and ostracods. These microfossils have been extracted 'in the round' from the shales and are described herein.

Although foraminifera are often found 'in the round' in shale-prone facies they are difficult to identify because the classification and systematics of this group are based on internal morphological features. The usefulness of this group is therefore somewhat diminished by the present lack of knowledge of external

\begin{tabular}{|c|c|c|c|}
\hline$A G E$ & $\begin{array}{l}\text { SOUTH } \\
\text { CUMBRIA }\end{array}$ & $\begin{array}{l}\text { NORTH } \\
\text { CUMBRIA }\end{array}$ & $\begin{array}{c}\text { ASBIAN } \\
\text { STRATOTYPE }\end{array}$ \\
\hline $\begin{array}{c}\text { LATE } \\
\text { ASBIAN }\end{array}$ & $\begin{array}{l}\text { 'UPPER' } \\
\text { URSWICK } \\
\text { LIMESTONE }\end{array}$ & $\begin{array}{c}\text { FIFTH } \\
\text { LIMESTONE }\end{array}$ & $\begin{array}{l}\text { KNIPE SCAR } \\
\text { LIMESTONE }\end{array}$ \\
\hline EARLY & $\begin{array}{l}\text { WOODBINE } \\
\text { SHALE }\end{array}$ & $\begin{array}{l}\text { CHONETES } \\
\text { SHALE }\end{array}$ & SANDSTONE \\
\hline ASBIAN & $\begin{array}{l}\text { 'LOWER' } \\
\text { URSWICK } \\
\text { LIMESTONE }\end{array}$ & $\begin{array}{l}\text { SIXTH } \\
\text { LIMESTONE }\end{array}$ & $\begin{array}{l}\text { POTTS BECK } \\
\text { LIMESTONE }\end{array}$ \\
\hline HOLKERIAN & $\begin{array}{c}\text { PARK } \\
\text { LIMESTONE }\end{array}$ & $\begin{array}{c}\text { FIFTH } \\
\text { LIMESTONE }\end{array}$ & $\begin{array}{l}\text { ASHFELL } \\
\text { LIMESTONE }\end{array}$ \\
\hline
\end{tabular}

Fig. 1. Stratigraphic framework for Holkerian and Asbian of Cumbria.

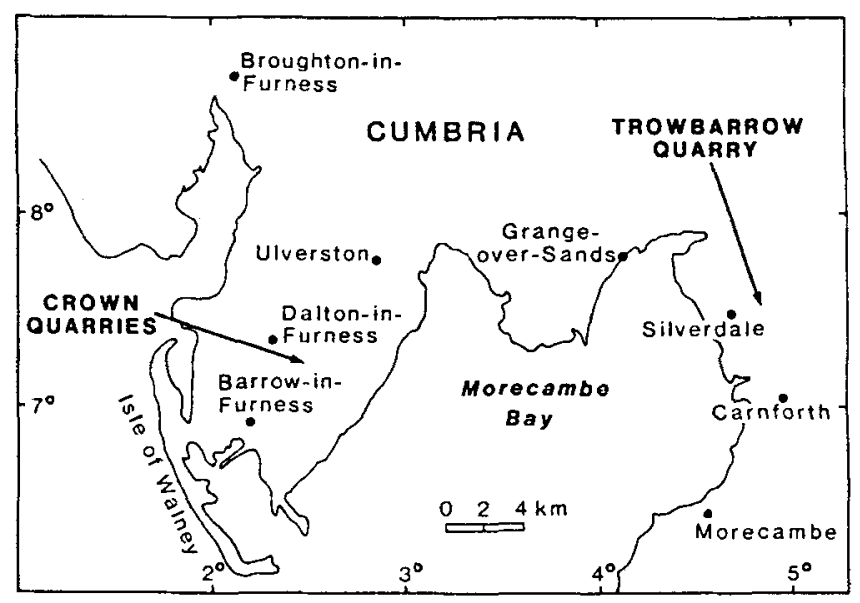

Fig. 2. Location map of study area. 
features. However, current research is attempting to document the foraminifera found in shales to describe their external features and to identify each taxon by preparing thin sections of individual specimens (Athersuch \& Strank, unpublished). These taxa may then be used in the dating and correlation of clastic Dinantian facies.

Ostracods occur in abundance in the Woodbine Shale. Very little has been published on the ostracods of the area and little is known about their stratigraphic usefulness. By examining ostracod faunas from the shales within well dated Dinantian successions, the chronostratigraphic significance of individual ostracod taxa will gradually be documented.

The aims of the current study are twofold: (i) to date the Woodbine Shale and the Urswick Limestone, to verify the previously assumed lithostratigraphic correlation (see Figure 1) and (ii) to examine foraminifera and ostracods 'in the round' to establish their stratigraphic significance in the Dinantian.

This study forms part of an ongoing research project; the specimens illustrated have not been deposited at present in any collections, nor have they been catalogued. They are stored in the B.P. Stratigraphy Branch research collections at the B.P. Research Centre, Sunbury-on-Thames.

\section{TROWBARROW QUARRY}

Trowbarrow Quarry (now disused) displays a magnificent sequence of almost vertically bedded Urswick Limestone. Microfaunal samples were collected at one metre intervals throughout the limestones and randomly within the relatively poorly exposed Woodbine Shale. A detailed log is shown in Figure 3 (adapted from Grayson's unpublished Palaeontological Association, Carboniferous Group Field Guide, 1973).

\section{(a) The Lower Urswick Limestone}

Previous palaeontological investigations have failed to yield any age diagnostic fauna from these beds. Local lithostratigraphic correlations have suggested either a Holkerian or an early Asbian age, with the overlying Woodbine Shale marking either the Holkerian/Asbian boundary or the early/late Asbian boundary. In the present study, the Lower Urswick Limestone yielded an abundant and diverse assemblage of foraminifera, most of which were well preserved. The occurrence of several Vissariotaxis compressa (Brazhnikova, 1967), Nudarchaediscus concinnus (Conil \& Lys, 1964) Gigasbia gigas (Strank, 1983) and, less frequently, Nibelia nibelis (Durkina, 1959) suggests an early Asbian age for these limestones. The occurrence of rare specimens of Cribrostomum is, however, usually indicative of a late Asbian (or younger) age, but this taxon has been previously recorded in the youngest beds of the early Asbian Potts Beck Limestone in the Asbian stratotype section Little Asby Scar, Cumbria (Strank, 1981). The overall fauna is very similar to that of the upper Potts Beck Limestone. Hence the age of the Lower Urswick Limestone exposed in Trowbarrow Quarry is, on foraminiferal evidence, taken to be late early Asbian in age.

Associated taxa in the Lower Urswick Limestone include Plectogyranopsis convexa (Rauser, 1948), Biorbis duplex (Strank, 1983), Neobrunsiina sp., Pseudolituotuba wilsoni (Conil \& Longerstaey, 1980), Archaediscus stilus (Grozdilova and Lebedeva, 1953), Valvulinella youngi (Brady, 1876), Cribrospira sp. and large angulatus stage archaediscids, together with the algae Koninckopora inflata (de Koninck, 1842) and $K$. mortelmansi (Mamet, 1973). (See Strank, 1981 for a full faunal list).

\footnotetext{
Explanation of Plate 1

Foraminifera \& Algae from the Lower Urswick Limestone Trowbarrow Quarry (Random thin sections)

Fig. 1. Forschia sp equatorial section $(\times 75)$.

Fig. 2. Omphalotis minima (Rauser and Reitlinger), equatorial section $(\times 75)$.

Fig. 3. Cribrostomum aff. lecomptei Conil \& Lys, $(\times 75)$.

Fig. 4. Plectogyranopsis ampla Conil \& Lys, equatorial section $(\times 75)$.

Fig. 5. cf. Cribrospira mira Rauser, equatorial section $(\times 75)$.

Fig. 6. Koninckopora tenuiramosa Wood $(\times 75)$.

Fig. 7. Nodosarchaediscus sp. $(\times 140)$.

Fig. 8. Nudarchaediscus spirillinoides Rauser, axial section $(\times 140)$.

Fig. 9. ?Vissariotaxis sp./Howchinia sp. $(\times 75)$.

Fig. 10. Pseudolituotuba cf. extensa Conil and Longerstaey $(\times 75)$.

Fig. 11. Vissariotaxis compressa (Brazhnikova), axial section $(\times 75)$.

Foraminifera from the Lower Urswick Limestone below the Woodbine Shale, Stainton Quarry (Random thin sections).
}

Fig. 12. Vissariotaxis sp. axial section $(\times 75)$.

Fig. 13. Cribrospira panderi Moeller, equatorial section $(\times 75)$.

Fig. 14. Gigasbia gigas Strank $(\times 75)$. 
Foraminifera and Ostracods from the Dinantian Woodbine Shale and Urswick Limestone, South Cumbria, U.K.
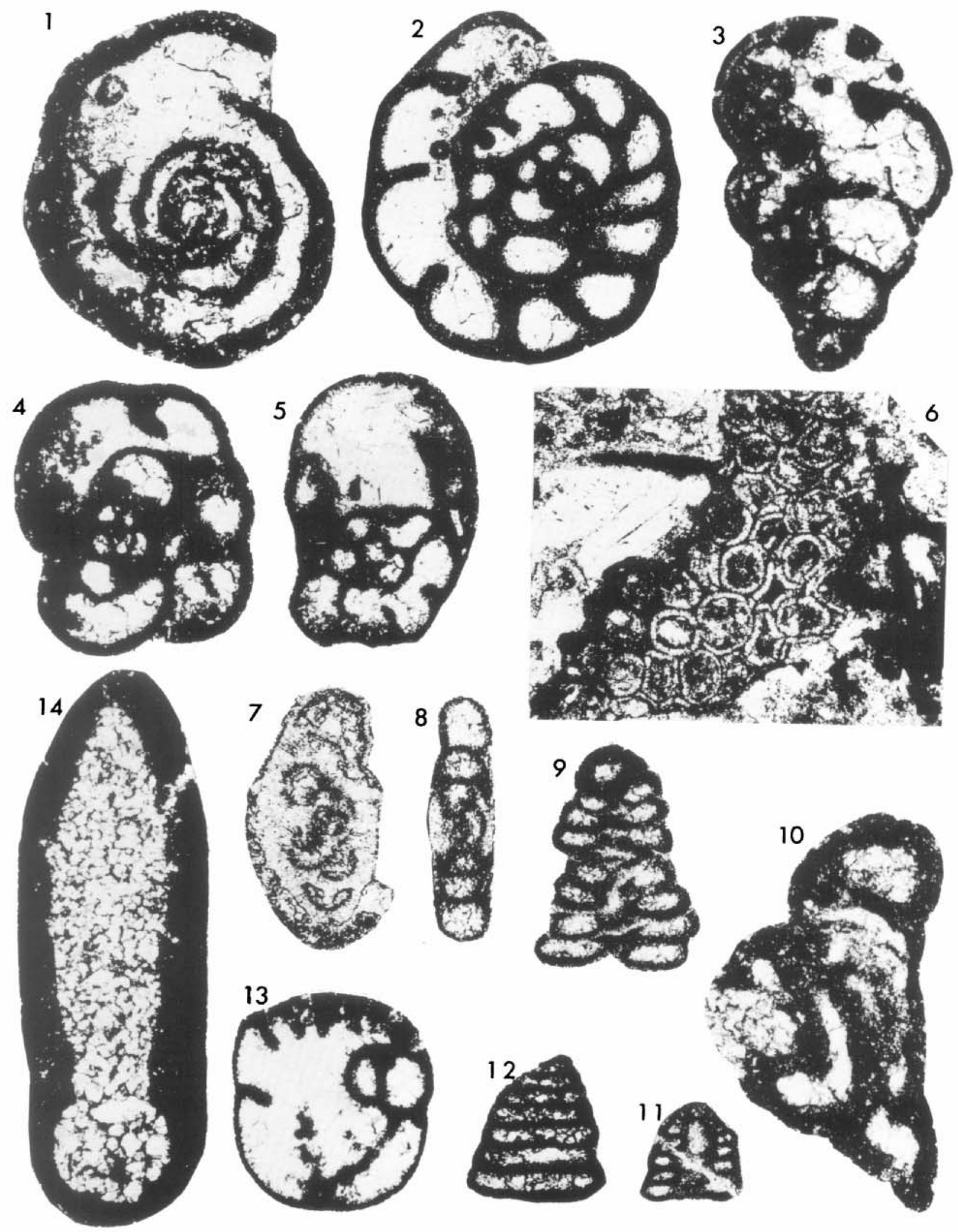
(b) Woodbine Shale

(i) Foraminifera. Samples from the Woodbine Shale yielded abundant, well preserved foraminifera. Very little is known about the external morphology of Dinantian foraminifera due to the traditional practice of examining internal morphological features of these microfossils in random thin sections. This random section technique was developed because of the difficulty of efficiently separating calcareous microfossils from their carbonate matrix. In this study solid foraminifera from the Woodbine Shale were photographed prior to being individually thin sectioned and identified, thereby providing a rare opportunity to study the external characteristics of taxa previously described only in thin section (Plates 2-4).

In this early stage of research, identification of the solid foraminifera from the external morphology is difficult beyond a broad family or occasionally, generic level. Examination of these specimens in thin section (Plate 4) has revealed several specimens of Palaeotextularia ex gr. longiseptata (possibly Cribrostomum) a form not found in beds older than latest early Asbian. The associated fauna including Tetrataxis paraminima (Vissarionova, 1984), Eostaffella parastruvei (Rauser, 1948), Koskinotextularia sp., Archaediscus sp., Endothyra ?maxima (Zeller, 1953), and Valvulinella sp. could be either early or late Asbian in age but in view of the absence of otherwise commonly occurring late Asbian markers, a probable latest early Asbian age is preferred (but see also evidence from the ostracods and macrofauna (ii and iii). It is of course possible that potential late Asbian markers may be absent due to facies control i.e. they occur abundantly in the overlying limestones but not in the shales.

(ii) Ostracods. Seventeen species of ostracod were recovered from the Woodbine Shale at Trowbarrow Quarry (see Plates 5 and 6). The assemblage was very rich and dominated by bairdiids belonging to several

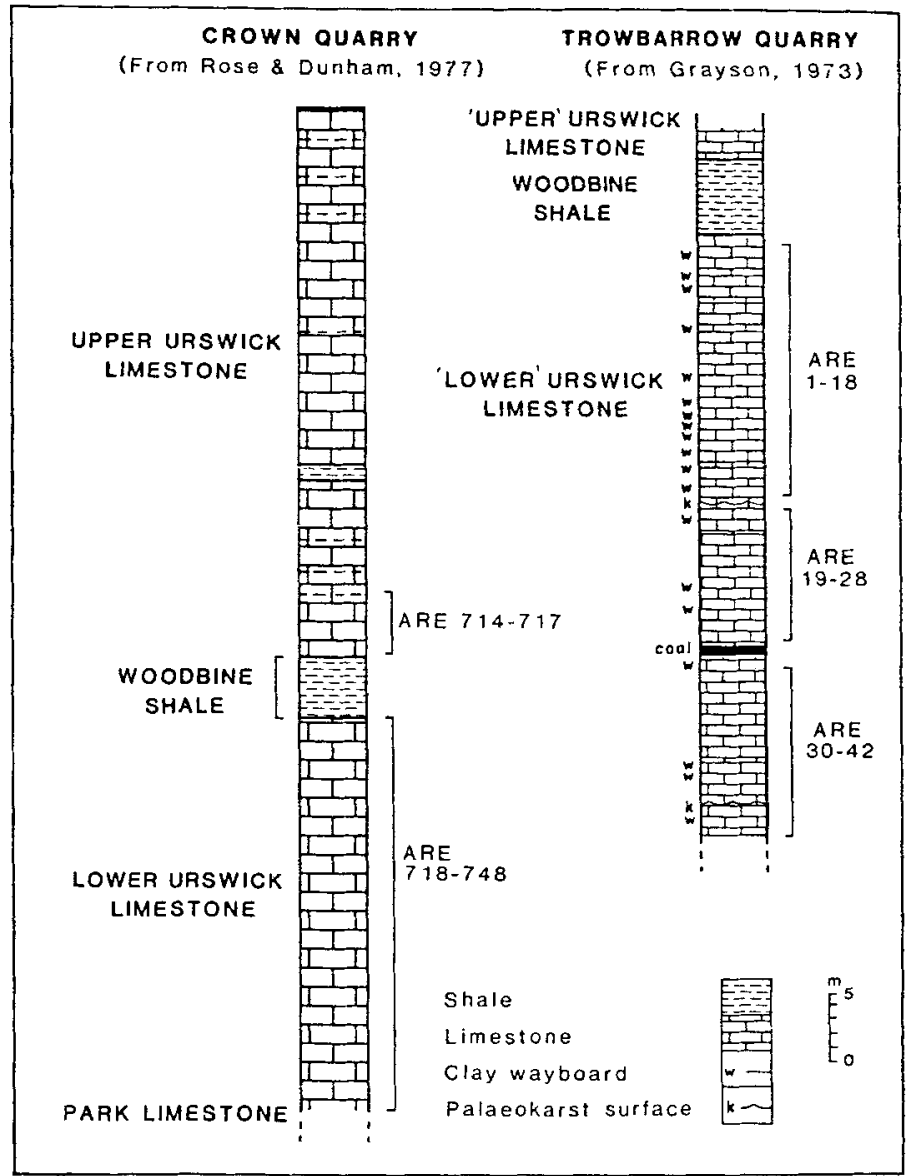

Fig. 3. Generalised stratigraphic sections at Crown Quarries, Barrow-in-Furness, and Trowbarrow Quarry, Silverdale.

genera and species; Amphissites sp., Healdia "penchfordensis" Robinson, 1980 nom. nud) Microcheilinella cf. subcorbulinoides (Jones \& Kirkby, 1885), Microcheilinella sp., Cavellina cf. valida (Jones,

\section{Explanation of Plate 2}

\section{Foraminifera from the Woodbine Shale, Trowbarrow Quarry}

Figs. 1-2. Tetrataxis paraminima (Vissarionova). 1, apertural view; 2 , axial view $(\times 75)$. Figured thin section $\mathrm{Pl} .4$, Figure 1.

Figs. 3-4. Valvulinella ?conciliata (Ganelina), 3, axial view; 4, apertural view $(\times 75)$. Figured thin section Pl. 4, Figure 4.

Fig. 5. ?Gen. nov. ?triserial Palaeotextulariidae, axial view $(\times 75)$.

Fig. 6. Koskinotextularia ?cribriformis (Eickhoff), axial view showing cribrate aperture $(\times 40)$.

Figs. 7-8. ?Koskinotextularia sp., 7, axial view; 8 , apertural view showing cribrate aperture $(\times 40)$. Figured thin section Pl. 4, Figure 12.

Figs. 9-10. Palaeotextularia ex gr. longiseptata, 9, axial view; 10, apertural section showing simple looped aperture $(\times 50)$. Figured thin section Pl. 4, Figure 6 .

Figs. 11-12. Palaeotextularia ex gr. longiseptata, 11, axial view; 12, apertural view showing ?simple aperture $(\times 75)$. Figured thin section Pl. 4, Figure 7.

Figs. 13-14. Palaeotextulariidae; 13, axial view; 14, apertural view showing simple aperture $(\times 75)$. Figured thin section Pl. 4, Figure 13. 
Foraminifera and Ostracods from the Dinantian Woodbine Shale and Urswick Limestone, South Cumbria, U.K.

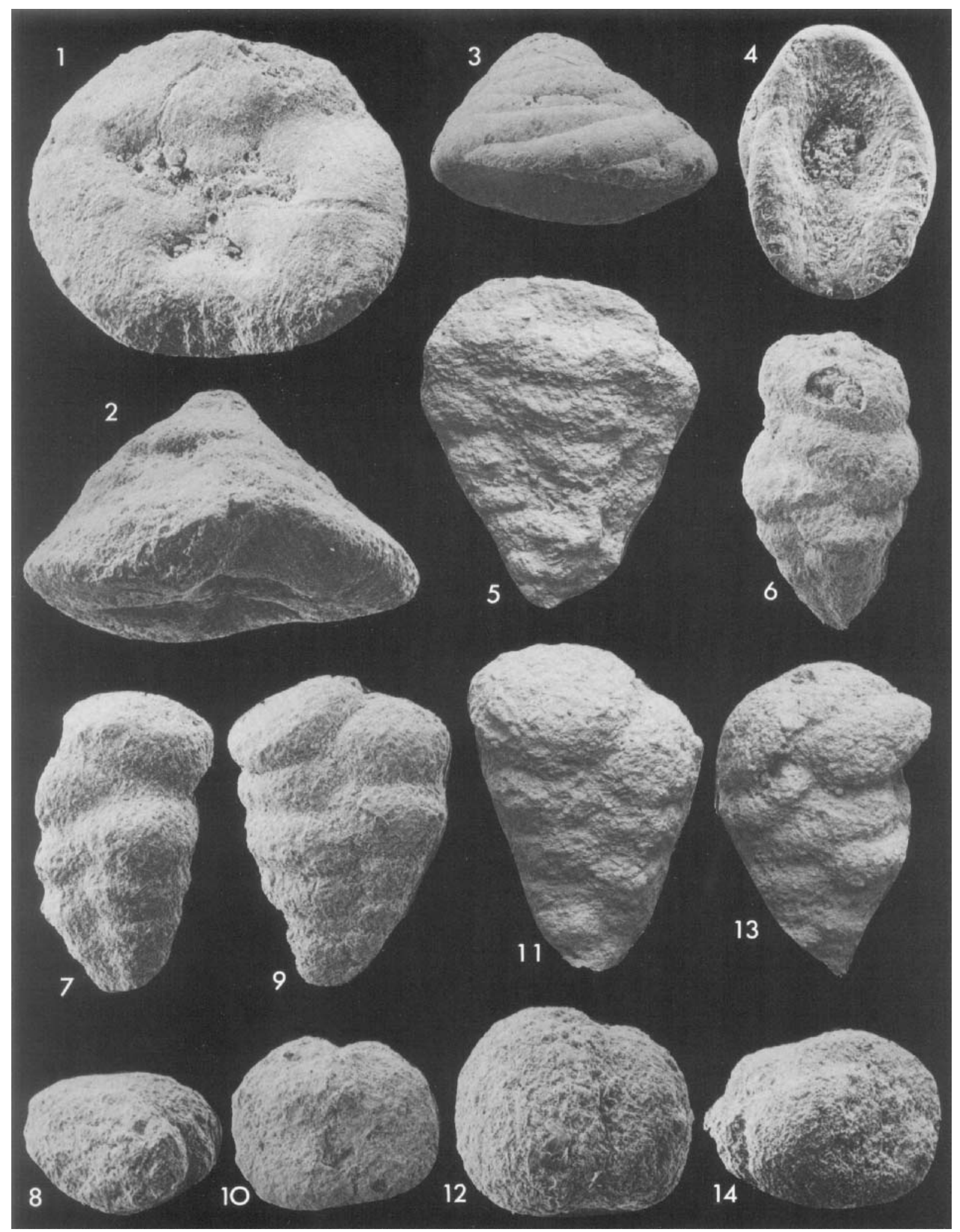


Kirkby \& Brady, 1884) and ?Pseudobythocypris cf. cuneola (Jones \& Kirkby, 1886) were common; Ectodemites sp., Coryellina sp. and Hollinella sp. were extremely rare. The ostracods independently suggest a late Asbian rather than an early Asbian age; this conclusion is based on a comparison of the individual taxa with those recorded from other U.K. and Irish localities (Robinson, 1978, 1980; ten Have, 1982; Mason, 1983). The abundance of bairdiids alone would suggest a late Asbian age (Robinson, 1978). (The apparent age discrepancy given by the ostracods compared with the foraminifera is discussed in section iv).

Most of the ostracod taxa have been recorded in open nomenclature, but will be fully described at a later date when the current survey of British Dinantian faunas is further advanced.

The bairdiids comprise Rectobairdia sp. similar to those recorded as $R$. dorssenata Robinson by Robinson (1978; 1980), and identical to $R$. sp. F. Sohn, 1960 in Mason (1983), both from the late Asbian to early Brigantian strata of the U.K. Other specimens are similar to Rectobairdia cf. magna (Tschigova, 1960) described by Mason (1983) from the late Asbian; these individuals resemble neither $R$. magna as originally described nor $R$. aff. magna of Robinson (1978). Bairdia cf. leguminoides (Ulrich, 1891) was also identified; it is similar to $B$. cf. leguminoides described from the late Asbian by Mason (1983). Pustulobairdia cf. confragosa is represented by several specimens which are identical to $P$. confragosa (Samoilova and Smirnova 1960) illustrated by Mason (1983) from Chadian, late Asbian and Brigantian rocks but which differ from $P$. confragosa of Robinson $(1978 ; 1980)$ which has a late Asbian distribution in the U.K.; no comparison has been made with the original description of $P$. confrago$s a$. Three other bairdiid taxa were present in this material but have not been identified.
Amphissites sp., which occurs frequently in the Woodbine Shale, is not attributable to any known species; it is similar to a number of species recorded from N. America, N.W. Europe and Russia, including A. mosquensis Posner, 1951, A. verrucosus Zanina, 1956, A. centronotus Ulrich and Massler, 1906, and $A$. centronotus transversa Roth, 1928, but differs from them all in the details of the ornament. These forms together range throughout the Carboniferous. The most similar is A. cf. centronotus of ten Have (1982) from the Courceyan to Asbian of Ireland and the Asbian to Brigantian of England.

Healdia "penchfordensis" was originally recorded from the late Asbian of the Northumberland Trough by Robinson (1980). Unfortunately, the species was never described and the name "penchfordensis" is therefore a nomen nudum under the terms of I.C.Z.N. Art. 16. Mason (1983) also recorded this species from the late Asbian of the U.K.

Two species of Microcheilinella were recognised. One is not specifically identifiable, the other is referred to $M$. subcorbulinoides (Jones \& Kirkby), a species recorded from late Asbian and Brigantian rocks in the U.K. by Robinson $(1978,1980)$ and by Mason (1983); the latter author also recorded it from Chadian and Arundian strata.

Specimens of Cavellina resemble C. valida (Jones, Kirkby \& Brady) recorded from Asbian and late Brigantian strata by Robinson $(1978 ; 1980)$ and from the late Asbian by Mason (1983).

Pseudobythocypris cf. cuneola, which was abundant in our material, closely resembles $P$. cuneola (Jones \& Kirkby) recorded from Holkerian to Pendleian rocks, with an acme in the Asbian to Brigantian, by Robinson (1978). Mason (1983) also recorded similar specimens under the name ?P. cf. pyrula (Jones \& Kirkby) from the late Asbian.

\section{Foraminifera from the Woodbine Shale, Trowbarrow Quarry}

Figs. 1-2. Endothyranopsiinae (probably Plectogyranopsis sp.), 1, umbilical view; 2, apertural view $(\times 75)$. Figured thin section PI. 4, Figure 5.

Figs. 3-4. Endothyranopsis crassa (Brady), 3, umbilical view; 4, apertural view $(\times 75)$. Figured thin section, Pl. 4, Figure 2. Additional specimen $\times 100$, Pl. 4, Figure 3 .

Figs. 5-6. Eostaffella parastruvei (Rauser), 5, umbilical view; 6, apertural view $(\times 75)$. Figured thin section Pl. 4, Figure 11.

Figs. 7-8. Endothyra ?maxima; 7, apertural view with terminal 'spine'; 8, umbilical view ( $\times 75)$. Figured thin section, Pl. 4, Figure 8.

Fig. 9. Eostaffella parastruvei (Rauser), umbilical view $(\times 75)$.

Figs. 10-11. Endothyra sp., 10, apertural view; 11, umbilical view $(\times 75)$.

Figs. 12-13. Endothyra sp., 12, apertural view; 13, umbilical view $(\times 75)$.

Figs. 14-15. Archaediscidae, almost planispiral form. 14, apertural view; 15, equatorial view $(\times 140)$. Figured thin section Pl. 4, Figure 10.

Figs. 16-18. Archaediscidae, 16, 18, apertural views; 17, equatorial view $(\times 140)$. 


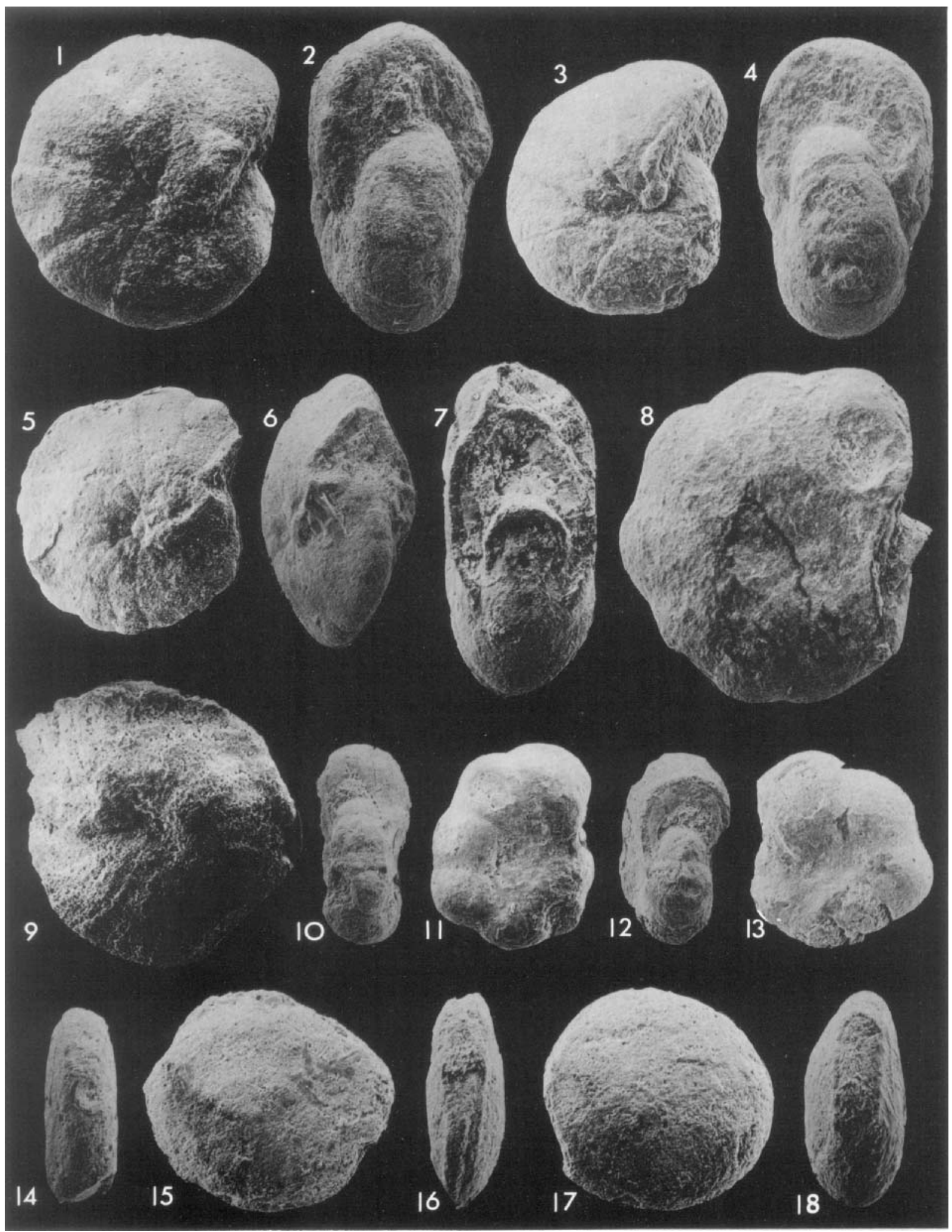


The rare specimens recorded as Ectodemites sp. are not assigned to any known species. They resemble a number of Ectodemites spp. described from Brigantian to Namurian A equivalents of $\mathrm{N}$. America by Cooper (1946).

A single internal mould of Hollinella was recovered; it may be referable to $H$. radiata (Jones \& Kirkby, 1886), a species which ranges throughout the Dinantian (Robinson, 1978). The stratigraphic significance of a single specimen of ?Coryellina and of an indeterminate taxon is not known.

(iii) Macrofauna. Samples of the Woodbine Shale yielded macrofossil assemblages comprising abundant bivalves and brachiopods, and common trilobites identified as Cummingella jonesii (pers. comm. N. J. Riley, BGS Keyworth). This species has not previously been recorded from strata younger than early Asbian and its presence therefore supports an early Asbian age.

(iv) Age. The early and late Asbian divisions are somewhat arbitrary as they have not been formally defined. The terms early and late Asbian used herein correspond to the stratigraphy at the Asbian stratotype section, i.e. the Potts Beck Limestone is early Asbian in age and the Knipe Scar Limestone is late Asbian in age.

By virtue of its stratigraphic position between the early Asbian Lower Urswick Limestone and the late Asbian Upper Urswick Limestone, the Woodbine Shale is latest early Asbian or earliest late Asbian in age. A latest early Asbian age is favoured by the trilobites and foraminifera whereas the ostracods indicate a late Asbian age to be more likely. The stratigraphic distribution of the foraminifera and trilobites is well known in the Central Northern Province whereas the ranges of ostracods have been taken mainly from their occurrences in the Northumberland Trough where the early Asbian is difficult to recognise using microfauna due to little published research in this area. The balance of evidence, therefore, favours a latest early Asbian age.

At the Asbian stratotype Little Asby Scar, Cumbria, a sandstone separates the early Asbian Potts Beck Limestone from the late Asbian Knipe Scar Limestone. It seems probable, therefore, that the Woodbine Shale is the time equivalent of this sandstone. Likewise in North Cumbria the Chonetes Shale separating the early Asbian Sixth Limestone (Strank, 1981) from the late Asbian Fifth Limestone is probably equivalent in age to the Woodbine Shale.

(v) Depositional Environment. The diversity and abundance of the ostracod fauna and the presence of bairdiids, together with heavily ornamented forms such as Amphissites and Ectodemites suggests a subtidal, marine environment of deposition (Becker et al., 1974). This conclusion is supported by the accompanying macrofauna which comprises brachiopods, trilobites and diverse, abundant foraminifera.

(c) The Upper Urswick Limestone

Above the Woodbine Shale, the Upper Urswick Limestone displays some spectacular palaeokarst surfaces, clay wayboards, coals and extensively burrowed horizons (Fig. 3). The foraminifera present in this unit contrast markedly with those found in the Lower Urswick Limestone. The appearance of abundant stellate archaediscids, Biseriella sp. and Howchinia bradyana Howchin, 1888, and the absence of Brigantian markers suggests a late Asbian age. On biostratigraphic evidence the Upper Urswick Limestone correlates with the Knipe Scar Limestone of the Asbian stratotype section at little Asby Scar, Cumbria.

\section{CROWN QUARRY, STAINTON-IN-FURNESS}

In order to prove the suspected correlation of the Woodbine Shale in the Silverdale area with that at Furness, samples of the Woodbine Shale and the adjacent Urswick Limestone were collected at $1 \mathrm{~m}$ intervals at Crown Quarry, Stainton-in-Furness (Fig. 3).

\section{Explanation of Plate 4 \\ Foraminifera from the Woodbine Shale, Trowbarrow Quarry (Orientated thin sections)}

Fig. 1. Tetrataxis paraminima (Vissarionova), axial section $(\times 75)$. Figured solid specimen, Pl. 2, Figures $1 \& 2$. Figs. 2-3. Endothyranopsis crassa (Brady), axial section $(\times 75)$. Figured solid specimen, Pl. 3, Figures $3 \& 4 ; 3$, axial section $\times 100$.

Fig. 4. Valvulinella? conciliata (Ganelina), axial section $(\times 75)$. Figured solid specimen, Pl. 2, Figures 3 \& 4.

Fig. 5. Endothyranopsiinae (probably Plectogyranopsis sp.), equatorial section $(\times 75)$. Figured solid specimen, Pl. 3 , Figures $1 \& 2$.

Fig. 6. Palaeotextularia ex gr. longiseptata, axial section $(\times 50)$. Figured solid specimen, PI. 2, Figures $9 \& 10$.

Fig. 7. Palaeotextularia ex gr. longiseptata, axial section $(\times 75)$. Figured solid specimen, Pl. 2, Figures $11 \& 12$.

Fig. 8. Endothyra ?maxima, equatorial view $(\times 50)$. Figured solid specimen, Pl. 3, Figures $7 \& 8$.

Fig. 9. Eostaffella ?parastruvei (Rauser), equatorial view $(\times 75)$.

Fig. 10. Archaediscidae, almost planispiral form $(\times 140)$. Figured solid specimen Pl. 3, Figures 14 \& 15.

Fig. 11. Eostaffella parastruvei (Rauser), axial view $(\times 75)$. Figured solid specimen, Pl. 3, Figures $5 \& 6$.

Fig. 12. ?Koskinotextularia sp., axial section $(\times 40)$. Figured solid specimen, P1. 2, Figures $7 \& 8$.

Fig. 13. Palaeotextulariidae, axial section $(\times 75)$. Figured solid specimen, Pl. 2, Figures 13 \& 14. 
Foraminifera and Ostracods from the Dinantian Woodbine Shale and Urswick Limestone, South Cumbria, U.K.
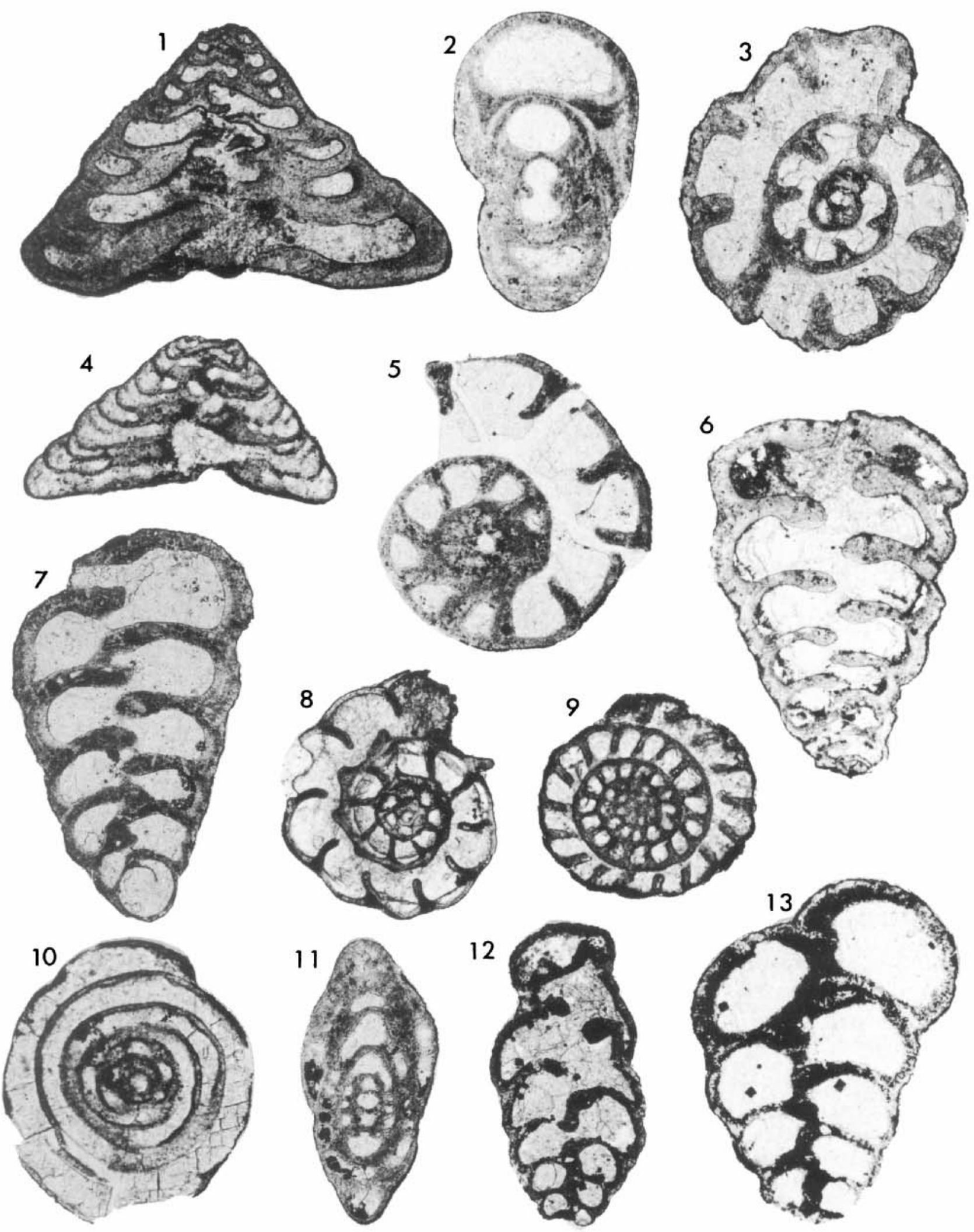
The Urswick Limestone underlying the Woodbine Shale yielded an abundant and diverse foraminiferal fauna. The presence of Gigasbia gigas Strank, 1983, Endothyra spira (Conil \& Lys, 1964), Cribrostomum sp. and Vissariotaxis compressa (Brazhnikova) suggests a late early Asbian age. The fauna is identical to that found in the upper part of the early Asbian Potts Beck Limestone at the Asbian stratotype section in Cumbria and in the lower Urswick Limestone in Trowbarrow Quarry, Silverdale.

Only a few samples were collected above the Woodbine Shale in this locality. The rather arenacous limestones yielded a rather restricted assemblage. However, the occurrence of a well-developed stellate archaediscid suggests an age within a late Asbian-early Namurian range for the Urswick Limestone overlying the Woodbine Shale. Since lithostratigraphical and biostratigraphical correlation in the area presents no evidence for a local unconformity (Rose \& Dunham. 1977), a late Asbian age is favoured. Samples collected from the Woodbine Shale in Crown Quarry have so far proven to be barren of diagnostic microfauna. However, correlation of this clastic unit with the shales at Trowbarrow is suggested by virtue of the chronostratigraphy of the adjacent limestones proposed herein for the two areas.

\section{CONCLUSIONS}

Foraminiferal and macrofaunal analyses have shown the Woodbine Shale in South Cumbria to be of latest early Asbian age. Associated ostracod faunas, including Rectobairdia sp., Bairdia cf. leguminoides, Pustulobairdia cf. confragosa, Healdia 'penchfordensis' and Microcheilinella subcorbulinoides, previously only known from late Asbian and younger strata, have now been shown to range into the early Asbian. The occurrence of numerous bairdiids together with heavily ornamented ostracods, trilobites, brachiopods and abundant foraminifera suggests a subtidal, marine environment of deposition for the Woodbine Shale.
Foraminifera in thin section from the underlying Lower Urswick Limestone suggest an early Asbian age whereas those from the Upper Urswick Limestone are indicative of a late Asbian age. The foraminiferal assemblages from these beds can be correlated directly with those in the early Asbian Potts Beck Limestone and the late Asbian Knipe Scar Limestone in the Asbian stratotype section, Little Asby Scar, Cumbria.

Solid foraminifera and ostracods from the Woodbine Shale have been described and illustrated for the first time.

\section{ACKNOWLEDGEMENTS}

The authors gratefuly acknowledge the financial support and technical assistance provided by the B.P. Research Centre, Sunbury, and B.P. Petroleum Development, Eakring. The loan of thin sections from BGS, Keyworth, and the assistance of Mr. M. Mitchell and Dr. W. H. C. Ramsbottom in the collection of material is much appreciated.

\section{Manuscript received February 1987 \\ Revised manuscript accepted September 1988}

\section{REFERENCES}

Aveline, W. T. 1873. Geology of the southern part of the Furness district in North Lancs. Mem. geol. Surv. U.K.

Becker, G., Bless, M. J. M., Streel, M. and Thorez, J. 1974. Palynology and ostracode distribution in the Upper Devonian and basal Dinantian of Belgium and their dependence on sedimentary facies. Meded. Rijks geol. Dienst, $N$. S., 25, 9-38.

Cooper, C. L. 1946. Pennsylvanian Ostracodes of Illinois. Bull. Ill. St. geol. Surv., 70, 1-177.

Dunham, K. C. and Rose, W. C. C. 1941. Geology of the iron-ore field of south Cumberland and Furness. Wartime Pamphl. geol. Surv. Engl. Wales, 16, 1-26.

Garwood, E. J. 1913. The Lower Carboniferous succession in the north-west of England. Q. Jl. geol. Soc. Lond., 68, $449-596$.

Grayson, R. 1973. (unpublished) Carboniferous Group Field Guide. Palaeont. Assoc. Guide.

\section{Explanation of Plate 5}

\section{Ostracods from the Woodbine Shale, Trowbarrow Quarry}

Each species is represented by lateral and dorsal views of the same specimen.

Figs. 1-2. Amphissites sp.; carapace, right and dorsal views $(\times 60$; length $965 \mu \mathrm{m})$.

Figs. 3-4. Ectodemites sp.; carapace, left and dorsal views $(\times 60$; length $890 \mu \mathrm{m})$.

Figs. 5-6. Microcheilinella cf. subcorbulinoides (Jones \& Kirkby); carapace, right and ventral views $(\times 150$; length $200 \mu \mathrm{m})$.

Figs. 7-8. Indeterminate genus and species; carapace, left and dorsal views $(\times 120$; length $415 \mu \mathrm{m})$.

Figs. 9-10. Microcheilinella sp.; carapace, right and ventral views $(\times 150$; length $275 \mu \mathrm{m})$.

Figs. 11-12. Hollinella sp.; partial internal mould of carapace, right and dorsal views $(\times 60$; length $1010 \mu \mathrm{m})$.

Figs. 13-14. Cavellina cf. valida (Jones, Kirkby \& Brady); carapace, left and dorsal views $(\times 50$; length $1290 \mu \mathrm{m})$.

Figs. 15-16. Healdia "penchfordensis" Robinson (M.S.); carapace, right and dorsal views ( $\times 150$; length $275 \mu \mathrm{m})$.

Figs. 17-18. ? Pseudobythocypris cf. cuneola (Jones \& Kirkby); carapace; right and dorsal views $(\times 120$; length $350 \mu \mathrm{m})$. 


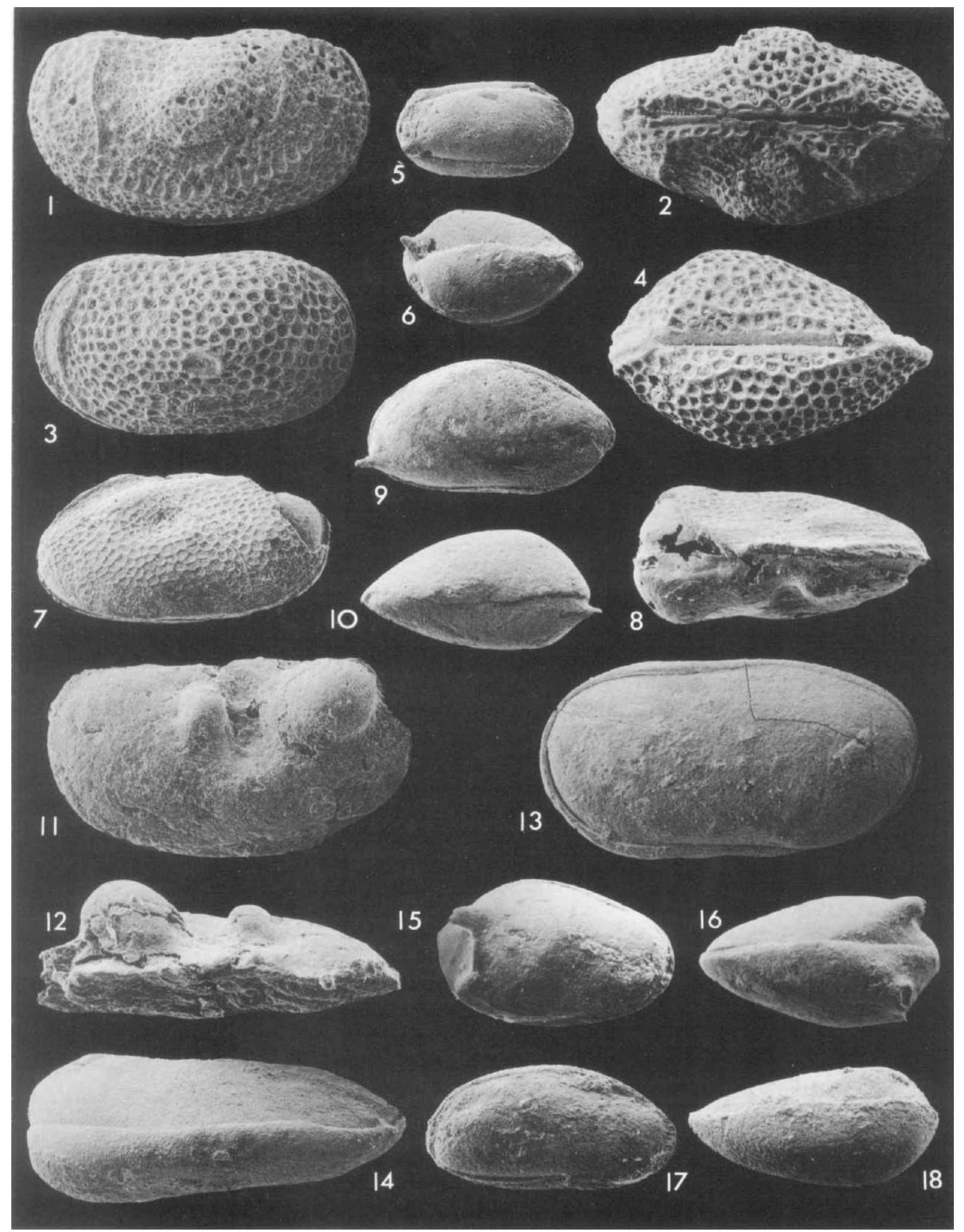


Mason, K. S. 1983. A Study of Lower Carboniferous (Dinantian) Ostracoda from certain localities within the Central Province. University of Manchester, PhD. Thesis. $361 \mathrm{pp}$.

Mitchell, M. 1977. In: Rose, W. C. C. and Dunham, K. C. 1977 - Geology and Haematite deposits in South Cumbria. Mem. geol. Surv. U.K.

Ramsbottom, W. H. C. 1973. Transgressions and regressions in the Dinantian: a new synthesis of British Dinantian stratigraphy. Proc. Yorks. geol. Soc., 39, 567-607.

Robinson, E. 1978. In: Bate, R. H. and Robinson, E. (Eds.). A Stratigraphical Index of British Ostracoda. Geol. J. Special Issue 8. Seel House Press, Liverpool. 538pp.

Robinson, E. 1980. In: Frost, D. V. and Holliday, D. W., Geology of the Country around Bellingham. Mem. Geol. Surv. U.K.
Rose, W. C. C. and Dunham, K. C. 1977. Geology and haematite deposits of south Cumbria. Mem. geol. Surv. $U . K$.

Sohn, I. G. 1960. Paleozoic species of Bairdia and related genera. U.S. geol. Surv., 330A, 1-105.

Strank, A. R. E. 1981. Foraminiferal biostratigraphy of the Holkerian, Asbian and Brigantian Stages of the British Lower Carboniferous. Unpub. PhD Thesis, University of Manchester.

Ten Have, M. R. 1982. Studies of Irish Lower Carboniferous Ostracods, 1 \& 2 Unpub. PhD Thesis, University of Dublin.

Tschigova, V. A. 1960. New ostracods from the DankovskLebedjansk, Chovansk and Lichvinsk deposits of the Russian Platform. Trudy-Vses. neft. nauchno-issled. Inst., 23, 205-233; 30, 169-233.

\section{Explanation of Plate 6}

Ostracods from the Woodbine Shale, Trowbarrow Quarry.

Each species is represented by lateral and dorsal views of the same specimen.

Figs. 1-2. ?Bairdia sp.; carapace, right and dorsal view $(\times 75)$; length $735 \mu \mathrm{m})$.

Figs. 3-4. Bairdia cf. leguminoides (Ulrich); carapace, right and dorsal views $(\times 120$; length $460 \mu \mathrm{m})$.

Figs. 5-6. Rectobairdia cf. magna (Tschigova); carapace, right and dorsal views $(\times 60$; length $890 \mu \mathrm{m})$.

Figs. 7-8. Rectobairdia cf. dorssenata Robinson; carapace, right and dorsal views $(\times 30$; length $2300 \mu \mathrm{m})$.

Figs. 9-10. ?Bairdia sp.; carapace, right and dorsal views $(\times 60$; length $810 \mu \mathrm{m})$.

Figs. 11-12. Pustulobairdia cf. confragosa Samailova \& Smirnova; carapace right and dorsal views $(\times 75$; length $690 \mu \mathrm{m})$.

Figs. 13-14. ?Bairdia sp.; carapace, right and dorsal views $(\times 120$ length $505 \mu \mathrm{m})$.

Fig. 15. ?Coryellina sp.; damaged left valve $(\times 60$; length $830 \mu \mathrm{m})$. 
Foraminifera and Ostracods from the Dinantian Woodbine Shale and Urswick Limestone, South Cumbria, U.K.

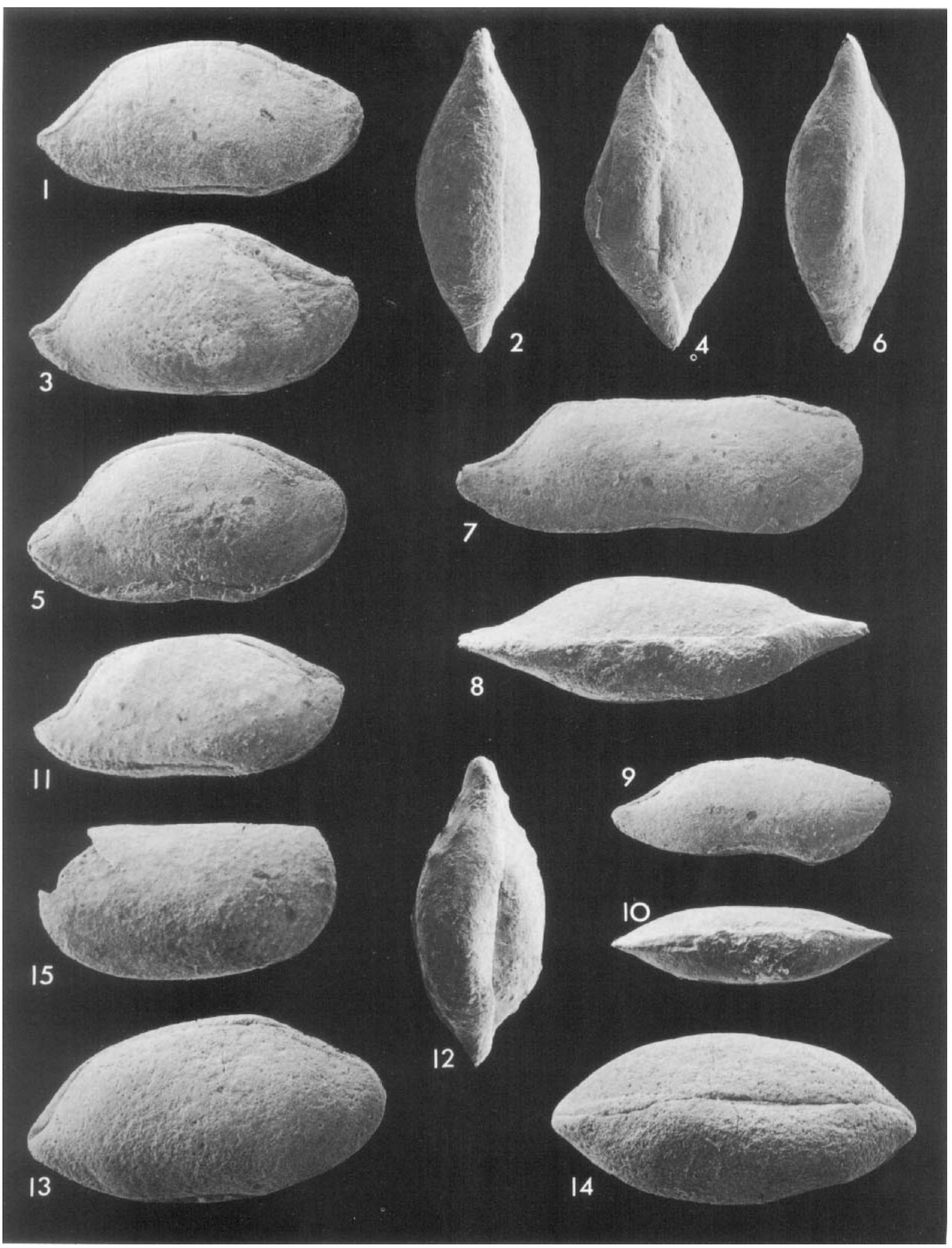

